\title{
MIX MARRIAGE (CANON 1124) The Ecumenical Spirit and Pastoral Approaches
}

\author{
Higianes Indro Pandego*
}

\begin{abstract}
Mixed marriage on the canon 1124, the 1983 Code refers to the marriage between Catholic and non-Catholic persons, which means that both of the persons are baptized. So, it must be the Sacrament (see can. 1055 §2). The Second Vatican Council picked the view of the people of God up based on the dignity of baptism. Then the Council expressed the idea of (full) communion in which the Catholic Church and the other Churches and communities have a relationship. To it Thus, The Council fosters the ecumenical movement that develops the union between the Christians, more especially concerning mixed marriage.
\end{abstract}

Key Word: Sacramentality of Marriage, notions of mixed marriage in the story, impediments, prohibition, spirit of Vatican Council, canon 1124 the 1983 Code, ecumenical spirit, pastoral movements.

\section{Introduction}

Two principles guide the Commission for the revision of the Code of Canon Law in 1968 i.e., supplement the Code 1917 with norms called for by the new situation of Christian life and adapt the future Code to the ecclesiology Second Vatican Council. The Commission then mentioned the 'fundamental unity' of the Church in its plurality and diversity rites. The 'ecumenical movement' of the Council manifested in the revised Code in which the Catholic Church has clarified in its law its relationship with non-Catholic Church and communities. ${ }^{1}$

The ecumenical movements involved the Catholic faithful, especially the theologians, at the beginning of the $20^{\text {th }}$ century and affected the Council's fathers. Inspired by the Holy Spirit, the Catholic

\footnotetext{
* Higianes Indro Pandego, licentiate in canon law; lulusan Universitas Gregoriana, Roma; dosen tetap pada Fakultas Filsafat Unika St. Thomas, Sumatera Utara.

1 Alexander Taché, "The Code of Canon Law of 1983 and Ecumenical Relations" in Le Nouveau Code de Droit Canonique - The New Code of Canon Law, Vol. 1 (Otawa-Ontario: Faculty of Canon Law Saint Paul University), hlm. 401.
} 
Church admitted the ecumenical movement among non-Catholics to realize visible unity. We can say that the $2^{\text {nd }}$ Vatican Council gave an official consecration for the Catholic Church's ecumenical movement. Furthermore, the Catholic Church has worked to fulfill her commitment to its vision of unity with Christ through this movement. ${ }^{2}$

The essential idea of the new Code on non-Catholic Churches and communities is about 'communion'. Documents of the Council, especially, Lumen Gentium $14-15^{3}$ and Unitatis Redintegratio $3^{4}$ point out concerning this idea. The idea of communion is one of the critical thoughts for understanding the early Church. The second Vatican makes it a fundamental concept of its ecclesiology, and the new Code must be we must understand it in this ecclesiology. ${ }^{5}$

The notion of communion includes some elements: participation in spiritual goods, co-possession of these same goods with others, and union with results from participation and co-possession. Communion, then, to be understood as the unity that finds its fundament in Christ and the Holy Spirit. However, it is not enough if the Church expresses the communion internally and spiritually. It must be a more concreted way that can be named juridical and brings the Church to common visible patterns of behavior, a common profession of faith, participation in the same sacraments, and submission to the same discipline laws. Shortly,

\footnotetext{
2 Taché, "The Code of Canon Law...., hlm. 402.

${ }^{3}$ In many ways the Church recognized those who being baptized are honored with the name Christian. They are consecrated by baptism in which they are united with Christ. See Documents Vatican II, Dogmatic Conctitution on the Church Lumen Gentium November 21, 1964) 14-15, English translated edision Documents Vatican II (Quezon City: Claretian Publication, 2014). This document shall henceforth be cited as LG in subsequent footnotes.

${ }^{4}$ In the beginning there is only one the Church of God. Furthermore, in subsequent centuries there are a large numbers of communities that separated from full communion with Catholic Church. However, in baptism they have a right to be called Christian. These our separated brethren are considered as Communities and Churches. See Decree on ecumenism Unitatis Redintegratio (December 4, 1963) 3, English translated edision Documents Vatican II (Quezon City: Claretian Publication, 2014). This document shall henceforth be cited as UR in subsequent footnotes.

5 Taché, "The Code of Canon Law...., hlm. 403.
} 
there are three elements of communion among the members of the Church, i.e., a profession of faith, sacraments, and ecclesial government. ${ }^{6}$

Apart from the communion related to the Eucharist, the new Code uses 34 times the term of communion. In an ecumenical context, the Code adds words 'with the Catholic Church,' and side by side with 'other Churches or ecclesial communities', deliberately to the communion term. As an addition, $L G$ 14-15 uses the word of communion referring to baptized non-Catholics. $^{7}$

Through the Secretariat for Christian Unity and other departments of the Roman Curia, the Apostolic See expresses its will to promote and direct the Catholic in the ecumenical movement. To foster 'harmonious relations between the Catholic Church and other Christian communities' is papal legates (can. 364, $6^{\circ}$ the 1983 Code). To tell about bishops' conferences, the Code declares its responsibilities to issue the norms declarations and promises of the Catholic party in a mixed marriage (cann. 1124-1126) and grant a dispensation form in a mixed marriage (can. 1127, §2). Book III of the 1983 Code, can. 755, fosters the bishops to develop ecumenical movement through their teaching and prophetic office in the Church. It is a competence of the ordinary of a diocese to grant permission for a mixed marriage (can. 1125). ${ }^{8}$

The exposition of this paper falls into two parts: 1) a series of questions about marriage in this ecumenical age; and 2) a foundational statement on the nature of the ecumenical movement. To discuss this topic, I assume a close familiarity with the legislation contained in the new Code (the 1983 Code) and the historical development that led up to it.

The questions depart from examination of the provisions of the revised Code on mixed marriages, i.e. cc.1124-1129. There are main questions: a) Are the norms satisfactory, considering the demands of the ecumenical movement? b) Do they respect the consciences of both Catholic and non-Catholic parties? c) Do they provide well for the

\footnotetext{
${ }^{6}$ Taché, "The Code of Canon Law...., hlm. 403.

7 Taché, "The Code of Canon Law...., hlm. 404.

8 Taché, "The Code of Canon Law...., hlm. 411-412.
} 
religious education of the children? d) How about the experience of the local Church to this topic? What could be done by simple cooperation of Christians Churches to uphold the dignity of Christian marriage and family?

\section{Fundamental Doctrins on Mix Marriage}

The origin of the Christian conception on mix marriage can't be separated from Christian's understanding on marriage itself. From the first centuries of Christianity, Christian's notion about marriage has its roots and sources in the Judaism or Hebrew tradition. Most of the first and may be also the second generation of Christians were religiously Jewish. They organized themselves continuous with Jewish history. ${ }^{9}$ For this reason, this part will begin from the biblical context that is the Old Testament and will be continued by the New Testament and Apostolic doctrines concerning of marriage.

\section{Biblical Doctrins on Mix Marriage}

The Genesis chapters 1-3 gives to the Christian the traditional notion on marriage. Ten centuries before Christ, the author of the text Genesis gave to the Hebrew audience his idea about husband-wife relationship. From the beginning and according to God's plan, the man and woman were to be most intimate physical and emotional partner. God formed them to live in a covenant of trust and in the intimate friendship of God. To cling to his wife, the man left or abandoned his parents and through this he created a covenant with his wife. In the expression, "and the two of them become one body," it is explained that the husband and wife became as one person before the law. Here they form the closest and most indestructible relationship conceivable legally, emotionally and socially. This characteristic of the relationship is deemed and dealt as sacramental. Thus, the Christian teachers has

\footnotetext{
${ }^{9}$ See Theodore Mackin, Marriage in the Catholic Church - The Marital Sacrament (New York Mahwah: Paulist Press, 1989), hlm. 24.
} 
affirmed - reflecting the Genesis, that God himself created marriage and they have seen the deposits of marriage' sacramentality. ${ }^{10}$

The other element of marriage' sacramentality comes from the man-woman's obedience to the God's command, "Increase and multiply...". Considering that the man and his wife committed themselves to carry out God's mandate and committed themselves as a couple in union, they made a covenant with Him. Maintaining their covenant will be evidence of God's activity in the world. ${ }^{11}$

Beside of the sacramental value on the notion of Israel's marriage, the Hebrew Bible gives as well their rejection on mix marriage to keep well their identity as a nation and the people of God - the chosen people through the marriage. To protect their identity and their faith to Yahweh, the Deuteronomy prohibited the Israel to marry with pagan people. Therefore, one understands attitude strongly opposes the Jewish right to marry people who are not related to the Israelites. "When Yahweh your God has led you into the land you are entering to make your own, many nations will fall before you: Hittites, Girghasites, Amorites, Canaanites, Perizzites, Hivites and Jebusites.... You must make no covenant with them nor show them a pity. You must not marry with them: you must not give a daughter of yours to a son of theirs, nor take a daughter of theirs for a son of yours for this would turn away your son from follow me to serving other gods" (Deut. 7:1-5). ${ }^{12}$

Furthermore, an aversion to mixed marriages grows and becomes even more radical in situations historical of Israel community among the unfaithful nations. The danger of local nations attitude urged the Israel to rediscover and strengthen all that allows to consolidate their identity. Referring to the Jewish people's story, more especially at the time of the return of these people to the promised land after the Babylonian exile, we witness the rediscovery and reaffirmation of the law given by the Lord. It

\footnotetext{
${ }^{10}$ Mackin, Marriage in the Catholic Church, hlm. 24-32.

${ }^{11}$ Mackin, Marriage in the Catholic Church, hlm. 33.

12 Paolo Moneta, "Matrimoni e convivenze interconfessionali e internazionali I matrimoni tra persone di diversa fede religiosa" (Messina: Convegno Unione Giuristi Cattolici Messina, $30 \quad$ maggio 2014) hl.m. 2-3, in https:/ / translate.google.com/translate?hl=en\&sl=it\&u=http:/ / www.ugcmessina.it/Relazione_Prof.Mo neta.pdfeoprev $=$ searcheopto $=$ aue.
} 
was a crucial moment in the history of Israel to strengthen their identity rejecting the mix marriage with the strange women. ${ }^{13}$

We have an example of this attitude in the restoration work carried out (around the second half of 400 BC) by two essential characters. Two books of Sacred Scripture that is Ezra and Nehemiah, are dedicated. The book of Nehemiah says, "In those days I also saw that some Jews had married women from Ashdod, Ammon and Moab; half of their children spoke the Ashdod, none of them knew how to speak Judah but only the language of one people or another. I rebuked them, cursed them, beat some of them, pulled out their hair and made them swear to God: 'You will not give your daughters to their sons and you will not take their daughters for your sons or for yourselves'. Must we then hear it said that you too are committing this grave crime: playing traitor to our God by marrying foreign women?" (Nehemiah 13: 23-27). ${ }^{14}$

The question on mix marriage we can find in Saint Paul's community. St. Paul testified at the time of the first Christian communities: "If one of our brothers he has an unbelieving wife and she allows her to stay with him, you don't divorce her; and a woman that she has an unbelieving husband, if he allows him to stay with her, don't repudiate him: because the unbelieving husband is made holy by the believing wife and the unbelieving wife comes made holy by her believing husband" (1 Cor. 7:14). St. Paul does not want to against the principle of the indissolubility of marriage. However, he only says that the believing spouse can recover his freedom if the other abandons him or does not agree to live peacefully with him: "But if the unbeliever wants to separate, separate; in these circumstances the brother or sister are not subject to servitude; God has called you to peace!". ${ }^{15}$

\section{Apostolic Teachings to The Trent Council}

In the Catholic Church, the expression of mix marriage at first is like the Code named matrimonial mixtae religionis that exclusively

\footnotetext{
13 Moneta, "Matrimoni..., hlm. 3.

${ }^{14}$ Moneta, "Matrimoni..., hlm. 3.

15 Moneta, "Matrimoni..., hlm. 4.
} 
intended to a marriage between a catholic with a non-baptized, anciently with a pagan or Jews. Furthermore, it refers to the marriage with a baptized deviated into the heresy as well. Just after the two big schisms of the Christianity Oriental (XI century) and Occidental (XVI century), the term also indicated the marriage between a catholic with other confessions (orthodox or protestant). ${ }^{16}$

Since ancient times, mixed marriage has been the subject of Church Legislation. The Church has taken continuous charge of mixed marriages in the fourth century, promulgating adequate norms in order to ensure the faith of the ones united in marriage, either with pagans or with persons from various Christian communities, which have wandered away from the doctrine of the Apostles and of the Church. Intending these, there were canons 10 and 31 from the Council of Laodicea (year 343), canon 21 from the Council of Carthage (year 419), canon 14 from the Council of Chalcedon (year 451) and canon 72 of the Council of Constantinople in Trullo (year 691-692) that annulled marriages because the cases of perverted Christian faith increased, especially on the children resulting from these marriages. ${ }^{17}$

Affected by the debates in the provincial and ecumenical synods, the civil legislator then decided for those times: mixed marriages were annulled, effectively forbidding them. Then in 388, an imperial law declared it to be adultery, so annulling marriages between Christians and Jews, and the Code of Justinian (534) strengthened this prescription which being adopted by the Nomocanon of XIV titles. ${ }^{18}$

Before XI century, the documents official of Catholic Church used the term of matrimonio misto as a marriage between a catholic with

\footnotetext{
16 See Maria Amodio, "I matrimoni misti nella storia della Chiesa cattolica nell'ambito dell'Ecumenismo e del dialogo interreligioso" (Venezia: Università Ca' Foscari, 2012/2013) $8, \quad$ in http://dspace.unive.it/bitstream/handle/10579/4513/815093-1173350.pdf?sequence $=2$ (October 3, 2020 at 12.45 p.m.).

17 Maximilian Pal, "Mixed Marriages in the Canonical Legislation: a Brief Survey" (Theological Franciscan Institute of Roman) 123 in wmw.iuraorientalia.net> IO_03_2007, III_06_2007_Pal (October 3, 2020; at 11.00 a.m.).

18 Pal, "Mixed Marriages..., hlm. 124.
} 
a non-baptized. ${ }^{19}$ Since the 16 th century until the present time, there are many pontifical documents in which the Holy See has tried to rectify this juridical institution from all points of view. Some of these documents are regarding the Eastern Catholic Churches and even the Greek-Catholic Church in Romania. Particular synods did nothing but apply the apostolic instructions. $^{20}$

\section{Mix Marriage from the 1917 Code to the 1983 Code}

\section{The 1917 Code on Mix Marriage and The Following Documents}

Canons 1060-1064 of the Previous Code (the 1917 Code) gave the past legislation. It brought a lot of innovation to eliminate the danger of the Catholic party's faith and ensure that the parents provide religious education to the children born from these marriages. In this case, if the required guarantees do not exist, the wedding itself is stopped by Divine Law. $^{21}$

The West Church considered mixed marriage valid, even without the dispensation for a mixed marriage. She saw mixed marriage as an impediment that prevents, but not as an interdiction. The PioBenedictin Code of 1917 (can. 1060) and the former legislation of Eastern Churches confirmed this doctrine. Some theologians and canonists, as well as the Bishops Synod, suggested abolishing this impediment. As it would have prevented action by the priest and the bishop trying to avoid the dangers that a mixed marriage can bring, it limited the Catholic party's freedom to marry whoever it may choose and that it would be against the ecumenical spirit. ${ }^{22}$ The Pio-Benedictin Code (can. 1070) and motu proprio «Matrimonia Mixta» 2 established that mixed marriages between a baptized party and a non-baptized one were invalid without a dispensation from the impediment of religious disparity (in the former Eastern and Western discipline). ${ }^{23}$

\footnotetext{
${ }^{19}$ Amodio, "I matrimoni misti..., hlm. 8.

${ }^{20} \mathrm{Pal}$, Mixed Marriages..., hlm. 124.

21 Pal, Mixed Marriages..., hlm. 125.

22 Pal, Mixed Marriages..., hlm. 128-129.

${ }^{23} \mathrm{Pal}$, Mixed Marriages..., hlm. 128-129.
} 
In 1966, the Congregation for the Doctrine of the Faith (the Sant'Uffizio), by the instruction of «Matrimonium sacramentum», imposed only on the Catholic party the carrying out of the guarantees, while from the non-Catholic party a declaration, in which they specified knowing the duties of the Catholic party, was enough. But, as many Latin Catholics married baptized Eastern non-Catholics, Latin Bishops required for the prescriptions of the Vatican Council, regarding the form of mixed marriages between Eastern Catholics and baptized Eastern non-Catholics, an extension of the law to their territories too; leading to the issue of the decree Crescens matrimoniorum29 in 1967, by the Congregation for Eastern Churches. ${ }^{24}$

In 1967 the Synod of Bishops answered the problem enlightened by a new ecumenical institution. The Synod voted on the term either intending to the union between the catholic party and another an uncatholic party or a party non-baptized party. ${ }^{25}$ Following the doctrine of the Second Vatican Council, the Bishops' Synod in 1967 reexamined the entire issue regarding mixed marriages, refusing to replace the term mixed marriages with interreligious marriages. ${ }^{26}$

The Synod discussions led to Pope Paul VI issuing an Apostolic Letter given as a motu proprio «Matrimonia Mixta» in 1970. Since then, marriages concluded between any Catholic and non-Catholic, baptized or not, are called mixed marriages and not of mixed religions or religion disparity. $^{27}$

\section{The 1983 Code of Mix Marriage}

Marriages contracted between Catholics and non-Catholics, but baptized persons, are called mixed marriages. Marriages contracted between Catholics and non-Christians (Muslims, Jews, Buddhists, Hindus) are also called mixed marriages, but in this case, according to the law of the Latin and the Eastern Churches the Catholic contracting the

\footnotetext{
24 Pal, "Mixed Marriages..., hlm. 126.

25 Amodio, "I matrimoni misti..., hlm. 8.

${ }^{26}$ Pal, "Mixed Marriages..., hlm. 122.

${ }^{27}$ Pal, "Mixed Marriages..., hlm. 122.
} 
marriage has to ask for a dispensation from the impediment of disparity of religion. With the introduction of the 1983 Canon Law Code the term of disparity of religion disappeared from the canon dictionary, leaving in force the impediment. ${ }^{28}$

\section{The Notion of Mix Marriage in the Canon 1124 the 1983 Code}

Marriage between two baptized persons, one of whom was baptized in the Catholic Church or received into it after baptism, and the other a member of a Church or ecclesial community not in full communion with the Catholic Church, cannot be celebrated without the express permission of the competent authority.

We find two important changes in the Church's legislation contained in this canon. ${ }^{29}$ First, what is required is the express permission of the competent authority, that is of the local Ordinary. Without that permission, a marriage would be unlawful (contrary to the authoritative prohibition of Christ's Church), but not invalid (null and void). It should be noted however that a marriage between a Catholic and another baptized Christian celebrated without the required permission of the Ordinary may be invalid.

The Church's expresses her pastoral concern on the inevitable problems involved in any mixed marriage that should be fully understood. Every effort should enable the couples to face up to the implications of a mixed marriage.

Second, "The local ordinary is not to grant permission to assist at the marriage of a person who has notoriously rejected the Catholic faith unless the norms mentioned in can. 1125 have been observed with necessary adaptation (can. 1071§2). In cases where there is any doubt the priest should seek guidance from the local Ordinary.

\footnotetext{
28 Pal, "Mixed Marriages..., hlm. 122.

29 Catholic Bishops' Conference of England and Wales, "Mixed Marriages, Revised Directory (1990)" 10 in www.liturgyoffice.org.uk, Rites > Mixed Marriage (October 3, 2020 at 4.30 p.m.).
} 
The previous Code of Canon Law (1917) required a 'grave cause' to justify a dispensation. The New Code requires a Just and reasonable cause' and, following the decree 'Christus Dominus' of the Second Vatican Council establishes that a dispensation can be given in particular cases to the faithful whenever it is judged by the competent authority that 'it contributes to their spiritual welfare' (cf. can. $87 \S 1$ and 88). The same criterion of the spiritual welfare is a necessity a simple permission. A 'just and reasonable cause' should not be interpreted in a negative sense only. The Code also suggest that positive reason for the permission could be proposed. Thus the spiritual maturity of the couple and their ability to face up together to the difficulties of a mixed marriage would also be a just and reasonable cause for granting the required permission.

The declaration and promise of the Catholic partner (Canon 1125, $\left.\mathbf{1}^{\mathbf{0}}\right)^{30}$

The Church requires the Catholic partner makes declaration and promises as her pastoral responsibility to the future of the children of such marriages. It is her duty to Christ before she can approve of a mixed marriage. Therefore, priests should explain this carefully to the couple.

The promise for the children must be sincere. It is an honest and deliberate undertaking 'to do all that I can'. It means that all one can do in the marriage's actual circumstances, without endangering the marriage, within the marriage's unity. The other party is not required to give any undertaking in this matter, formally or informally. However, he or she must, of course, be informed of the Catholic's declaration and promise.

A couple contemplating marriage should agree before the wedding about the baptism and education of any children they may have. The priest, in this case, should encourage them to do this. However, the law does not require the Catholic's partner an assurance. A problem can indeed arise if the Catholic's partner is determined to prevail upon the Catholic to abandon their faith. The other difficulty may occur when they are determined to baptize their children (or some of them) outside the Catholic Church. This problem is acute when the other party adopts this

${ }^{30}$ Catholic Bishops' Conference, “Mixed Marriages..., hlm. 10-11. 
attitude from conscientious conviction. In these circumstances, the priest should discuss the issue in a friendly and helpful manner.

On informing the non-Catholic party about the promise and obligation of the Catholic party $\left(\text { Canon } 1125,2^{\mathbf{o}}\right)^{31}$

The other partner is informed as early as possible of the Catholic's obligations in conscience, which are expressed and acknowledged in the declaration and promise. Catholics must realize their responsibilities in this matter long before they come to arrange their marriage. Those who are involved in teaching should ensure that these obligations are known and understood. Thus, the friend is as free as possible to withdraw from the association if they would find respect for such burdens intolerable.

Concerning the instruction to be given to both parties (Canon 1125, $\left.\mathbf{3}^{\mathbf{0}}\right)^{32}$

This is not a requirement which is special to mixed marriages. It applies to all. The Prenuptial Enquiry form includes a reminder of the priest's duty to explain these points to all who seek marriage in the Catholic Church.

Canon 1063 reminds pastors of their obligation in this regard and of the importance of using every means available, including the church community, to see that marriage preparation is fruitful. Many dioceses will have their own programs, in addition to any national initiatives. Sections 47 to 52 of the Second Vatican Council's Pastoral Constitution on the Church ill the Modern World as a text from which engaged couples may be instructed on the Christian pattern for married life. What is being particularly insisted upon in this norm, however, is that people who are about to marry should know, and not exclude from their matrimonial consent, the elements essential to Christian marriage. These elements are:

\footnotetext{
${ }^{31}$ Catholic Bishops' Conference, "Mixed Marriages..., hlm. 12-13.

${ }^{32}$ Catholic Bishops' Conference, "Mixed Marriages..., hlm. 13-14.
} 
a. the essence of the matrimonial consent itself, namely, the exchange of the right to sexual intercourse which is open to the generation of new life;

b. the unity of marriage, namely that this right is to be exchanged with no other person during the lifetime of the other partner;

c. the permanence of marriage, namely, that this right is intended to remain as long as both live.

In leaving it to the Episcopal Conference to determine the way in which the declaration and promise are to be made, Canon 1126 insists again that this declaration and promise are always required. ${ }^{33}$

The procedure we require is that, when the Catholic applies to marry a person from a different Christian tradition or another faith, the priest to whom he or she applies must obtain all necessary certificates and fill up a form which specifies:

a. The name, and religious allegiance of each of the two people who propose to marry, the parish of the Catholic, and the fact that the Catholic has applied to the priest for permission or dispensation.

b. That the Catholic has given a declaration and promise (preferably in the presence of the other party) in the following words:

'I declare that I am ready to uphold my Catholic faith and to avoid all dangers of falling away from it. Moreover, I sincerely undertake that I will do all that I can within the unity of our partnership to have all the children of our marriage baptized and brought up in the Catholic Church.'

\section{The Ecumenical Spirit and Pastoral Approaches of Mix Marriage}

\section{Ecumenical Spirit from the Trent to the $2^{\text {nd }}$ Vatican Council's}

The Trent Council (1546-1563) is characterized as backward, reactionary and retrogressive event. It was a response to the Protestant

\footnotetext{
${ }^{33}$ Catholic Bishops' Conference, “Mixed Marriages..., hlm. 16.
} 
Reformation. Pope Paul III called the Council to clarify the doctrines that defined the bounderies between Catholic and Protestant thought, not for getting union. ${ }^{34}$

On other hand, the Second Vatican Council (1962-1965) took place a different historical backdrop. Pope John XXIII convoked the Council (January 25, 1959) to respond the new and unsetting world situation. His desire is to update the Church and to reach out the other Christians community. For getting aggiornamento and an effective ecumenism, he convinced that the Church need a renewal of its life. If the focus of Trent was on reform, by way of contrast the Vatican II was on renewal. The renewal includes a profound spiritual and a reaching out to the Churches separated from Rome. The Council was to be pastoral than dogmatic. As a result, the Council was able to bring a series of progressive changes on liturgy, pastoral, ecumenical, institutional and cultural. ${ }^{35}$

The Vatican II concerns to repair the differences that had ground since 1542. Decree on Ecumenism (1) articulates that the restoration of unity among all Christians is one of the principles concerns of the Second Vatican synod. The efforts of reconciliation and unity among Christians might carry over to the relationship toward non-Christians faiths. It means that, Vatican II fosters a redeveloping relationship (ecumenical and dialogue) both toward non-Catholics and non-Christians. ${ }^{36}$

\section{Ecumenical Manners after The Second Vatican Council}

The theory on ecumenism and marriage is properly a theological insight. It comes from the Second Vatican Council that brings the Church into a better understanding of the relationship between different Christian Churches and communities, in particular between the Roman Catholic communion and other communions of believers. The new insight says

\footnotetext{
34 Raymond F. Bulman, "Introduction: the Historical Context" in Raymond F. Bultman and Frederick J. Parella, ed., From Trent to Vatican II: Historical and Theological Investigation (New York: Oxford University, 2006), hlm. 3-4.

35 Bultman, "Introduction...", hlm. 9-11.

${ }^{36}$ Jeannine Hill Flecther, "Responding to Religions Differences: Conciliar Perspective" in Raymond F. Bultman and Frederick J. Parella, ed., From Trent to Vatican II..., hlm. 277.
} 
that diversity in beliefs does not cancel out the unity that exist through baptism and faith in the Lord Jesus. There is such thing as partial communion or communion by degrees. ${ }^{37}$

The practice focuses on the realization of the insight into disciplinary and structural changes as the Council has taken place in the Christian Churches, more especially in Roman Catholic communion. For the future, the practical aspect of the ecumenism and marriage may be the highest importance and urgency. All Christians communities should find themselves what they need to do in practice to facilitate the progress toward unity. ${ }^{38}$

Concerning the view of ecumenical movement, this paper proposes that it cannot be adequately defined as a steady effort in achieving progress in mutual understanding towards a commonly accepted Creed. Describing the ecumenical movement as an ongoing cooperative effort among Christian Churches for the sake of charitable and humanitarian causes is not enough. It is properly a movement of life. Through it, the mysterious, divinely granted and humanly circumscribed communities of Christian are growing together. It is more than a human effort to bring about federation. It is a gift from God being in our history. ${ }^{39}$ The Spirit of God who made one all those who are baptized and believe in Christ is the energy to carry the movement forward. In a real sense, the unity is already there and the purpose of the movement is to give full scope to this initial unity and to bring the minds and hearts of Christian people together, and to make them into one worshiping community. ${ }^{40}$

The Orthodox Church and the Catholic Church see the holy mystery of Christian wedding as a sacrament of Christ. The Orthodox perspective of Christian marriage is very close to Scripture and ancient Jewish tradition. The rite of marriage includes two parts that is sponsalia

\footnotetext{
${ }^{37}$ Ladislas Örsy, "Ecumenism and Marriage" in Michel Thériault and Jean Thorn, (ed.), Le Nouveau Code de Droit Canonique - The New Code of Canon Law, Vol. 2 (Ottawa: Faculty of Canon Law Saint Paul University, 1986) hlm. 1041.

38 Örsy, "Ecumenism and ..., hlm. 1041.

39 Örsy, "Ecumenism and ..., hlm. 1042.

40 Örsy, "Ecumenism and ..., hlm. 1042.
} 
(the exchange of rings) and coronation or nuptialia (marriage). The dogma of Orthodox tradition on marriage is closely connected to the Eastern view on the sacrament. It sees the image of Christ's spousal relationship with the Church. For that reason, in fact marriage, union between male and female is unique and unrepeatable that excludes all polygamy. $^{41}$

The Protestant Church understand that although belonging to God's plan of creation, marriage is not instituted by Christ as a necessary sign for the grace of salvation. Luther said that the term of sacramentum only refer to the relation between Christ and the Church, not between man and woman. However, he still needs a wedding liturgy in which was very close to the Catholic at that time. It is also similar to the position of Calvin. $^{42}$

The question of mixed-marriage (inter-confessional marriage) can be analyzed according the dogmatic and liturgical perspective. The mixed-marriage restricts the question only to marriage between baptized persons belonging to the different Churches: Catholic, Orthodox and Reformed (see can. 1124 CIC 1983). ${ }^{43}$ Departing from the similar or close perspective on marriage, they can develop a dogmatic-dialogue ecumenist on marriage and furthermore to realize it in ecumenicalcelebration of liturgy of marriage.

The 1983 Code, can. $1121 \S 3$ states on the possibility of the form canonical dispense. And it is clear that for the validity of marriage, there is a requirement of the presence of the local ordinary or pastor or priest or deacon delegated by either of them, and the presence of two witnesses as well (can. 1108). It still remains a first duty to celebrate the marriage between a Catholics and a baptized non-Catholic in a parish church, but with the permission of local ordinary or the pastor, it can be celebrated in another church or oratory (can. $1118 \S 1$ ). These canons give us a room

\footnotetext{
41 Gianandrea Di Donna, "Mixed-Marriages in the Liturgical Catholic Church Tradition" (Padova: Theological Faculty of Triveneto, 2018), hlm. 412-413 in https://doi.org/10.2478/ress-2018-0031.

42 Donna, "Mixed-Marriages..., hlm. 413-414.

43 Donna, "Mixed-Marriages..., hlm. 414.
} 
for celebrating together mixed-marriage in the ecumenical liturgy or worship.

By the 'form' of marriage is meant the formalities required for that public expression of consent by which the contract of marriage is made. Here Canon $1127 \S 1$ is dealing with 'canonical form', namely the formalities required by the law of the Church. ${ }^{44}$

These are that in all normal circumstances, when a Catholic is being married, the exchange of consent must be made before a properly authorized Catholic bishop, priest or deacon, and two witnesses. Canon $1108 \S 1$ says, 'Only those marriages are valid which are contracted in the presence of the local Ordinary or parish priest or the priest or deacon delegated by either of them, who, in the presence of two witnesses assists...' This requirement was introduced to eliminate the confusion which arose when people could claim the status of being married simply on the grounds that they had agreed together, even tacitly, to accept one another as man and wife. But even now, when the civil law eliminates this confusion, by demanding the registration of all marriages, the Church still insists upon canonical form. She does so for a pastoral and for a theological reason. ${ }^{45}$

The canon gives two reasons. provides. ${ }^{46}$ The first is pastoral reason that by this regulation every Catholic being married will be in touch with a Catholic priest who will then be able to offer all the pastoral help the Church provides.

The second is theological reason. In the case of marriage between Catholic and another baptized person is a sacrament. A sacrament is a sacred sign entrusted by Christ to his Church. In Christian marriage, we see a living symbol of Christ's love for his Church. Through this sacrament, the human love of husband and wife becomes a sign of undying faithful love. Because she sees the sacrament of marriage as sacred, and because she is so intensely concerned, the Church desires that her members confer and receive it before her accredited minister. Even

\footnotetext{
${ }^{44}$ Catholic Bishops' Conference, "Mixed Marriages..., hlm. 17.

${ }^{45}$ Catholic Bishops' Conference, "Mixed Marriages..., hlm. 17-19.

${ }^{46}$ Catholic Bishops' Conference, "Mixed Marriages..., hlm. 17-19.
} 
when a non-baptized person is involved, marriage remains sacred, and so the Church wishes it to be celebrated before her minister.

In the marriage of a Catholic with a partner of Oriental Rite not in full communion with the Catholic Church, for validity, it is sufficient for such a marriage to take place in the presence of a sacred minister of that partner's Rite. Still, for lawfulness, it is required that the Catholic party obtains the permission of his or her local Ordinary for the marriage to occur without canonical form (cf. the Decree of the Sacred Congregation for the Eastern Churches Crescens Matrimoniorum).

In the marriage of a Catholic with a Western person from another Christian tradition, the Church requires a canonical form. In such cases, a canonical form is required for validity. Therefore, a Catholic wedding must take place in a Catholic church-building and before an adequately authorized bishop, priest, or deacon and in the presence of two witnesses. This should be clearly explained to all Catholics. It should also be made dear to those who are not Catholics, especially those contemplating marriage with a Catholic. Popular over-simplification has led to a widespread impression that the Catholic Church is now indifferent as to whether a Catholic marries before a Catholic priest or not. As the next norm will insist, a serious reason is necessary for a bishop to dispense from canonical form.

Suppose there is a difficulty about a marriage being celebrated in a Catholic church-building. In that case, the local Ordinary can, for any good reason, allow the wedding to take place in some other suitable location, such as a building belonging to another Church or ecclesial community. The permission, merely concerning the wedding's place, supposes that it will nevertheless be conducted by a properly authorized Catholic bishop, priest, or deacon. There are legal difficulties concerning making this arrangement in Anglican churches, but it has sometimes proved an acceptable arrangement in other churches, but it has sometimes proved an acceptable arrangement in other churches.

We can see that in the circumstance of canonical form of marriage there is a possibility to foster the ecumenical cooperation. Beside of the places for marriage it will be better if the Catholic Church propose the 
form of consents to the other Christians tradition or the other Churches. Of course, the form must be allowed by the competent ordinary.

\section{Conclusion}

Mixed Marriage on the canon 1124 of the 1983 Code has its roots theologically in the scripture. Besides the sacrament meaning of Christian Marriage, the scripture warns the dangers of mixed Marriage. The challenges inside the mixed marriage foster the Church for many centuries to develop its notions on mixed Marriage, ought to impediment to prohibition and from Marriage between Catholic and non-baptized into Marriage between Catholic and non-Catholic.

The ecumenical spirit born in the Second Vatican Council affected the spirit of the 1983 Code, especially concerning mixed Marriage. The ecumenical movement around the mixed Marriage includes both theory level and practice. For that reason, I propose three efforts of ecumenical movements around the mixed Marriage. First, to develop a study of Christian Marriage, the sacramentality of Marriage between baptized persons appears. Second, to build a joint commission among Catholic and other Churches or communities on the level of Particular Church to find a canonical form of mixed Marriage that can be used together. And the last, to involve all Christians' participation in the period of preparation beforeat the time-and after the day of mixed Marriage; it means that the basic ecclesial communities participate in the continued formation of blended marriage families.

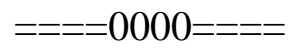




\section{BIBLIOGRAPHY}

The Second Vatican Council, Dogmatic Constitution on the Church Lumen Gentium (November 21, 1964) in Vatican Documents (Quezon City: Claretian Publications, 2014).

, Decree of Ecumenism Unitatis Redintegratio (November 21, 1964) in Vatican Documents (Quezon City: Claretian Publications, 2014).

Bulman, Raymond F. "Introduction: The Historical Context" in Raymond F. Bultman and Frederick J. Parella, ed., From Trent to Vatican II: Historical and Theological Investigation (New York: Oxford University, 2006).

Flecther, Jeannine Hill. "Responding to Religions Differences: Conciliar Perspective" in Raymond F. Bultman and Frederick J. Parella, ed., From Trent to Vatican II....

Mackin, Theodore. Marriage in the Catholic Church - The Marital Sacrament (New York - Mahwah: Paulist Press, 1989)

Örsy, Ladislas. "Ecumenism and Marriage" in Michel Thériault and Jean Thorn, (ed.), Le Nouveau Code de Droit Canonique - The New Code of Canon Law, Vol. 2 (Ottawa: Faculty of Canon Law Saint Paul University, 1986).

Thériault, Michel and Jean Thorn, editors. Le Nouveau Code de Droit Canonique - The New Code of Canon Law. Vol. 1. Ottawa: Faculty of Canon Law Saint Paul University, 1986.

Le Nouveau Code de Droit Canonique - The New Code of Canon Law. Vol. 2. Ottawa: Faculty of Canon Law Saint Paul University, 1986.

Amodio, Maria. "I matrimoni misti nella storia della Chiesa cattolica nell'ambito dell'Ecumenismo e del dialogo interreligioso" 
Higianes Indra Pandega. Mix Marriage (Canon1124)7he Ecumenical Spirit and Pastoral Approaches

(Venezia: Università Ca' Foscari, 2012/2013). http://dspace.unive.it/bitstream/handle.pdf? sequence $=2$

(October 3, 2020) .

Catholic Bishops' Conference of England and Wales, "Mixed Marriages, Revised Directory1990" in www.liturgyoffice.org.uk> Rites > Mixed Marriage (October 3, 2020).

Di Dona, Gianandrea. "Mixed-Marriages in the Liturgical Catholic Church Tradition" (Padova: Theological Faculty of Triveneto, 2018). https://doi.org/10.2478/ress-2018-0031

Pal, Maximilian. "Mixed Marriages in the Canonical Legislation: a Brief Survey" (Theological Franciscan Institute of Roman). www.iuraorientalia.net IO_03_2007 , III_06_2007_Pal (October 3, 2020). 